\title{
Report of the Annual Meeting
}

Rapports annuels de la Société historique du Canada

\section{Presidential Address}

\section{Hilda Neatby}

Volume 42, numéro 1, 1963

URI : https://id.erudit.org/iderudit/300610ar

DOI : https://doi.org/10.7202/300610ar

Aller au sommaire du numéro

Éditeur(s)

The Canadian Historical Association/La Société historique du Canada

ISSN

0317-0594 (imprimé)

1712-9095 (numérique)

Découvrir la revue

Citer ce document

Neatby, H. (1963). Presidential Address. Report of the Annual Meeting / Rapports annuels de la Société historique du Canada, 42(1), 1-18.

https://doi.org/10.7202/300610ar

All rights reserved $\odot$ The Canadian Historical Association/La Société historique du Canada, 1963
Ce document est protégé par la loi sur le droit d'auteur. L’utilisation des services d'Érudit (y compris la reproduction) est assujettie à sa politique d'utilisation que vous pouvez consulter en ligne.

https://apropos.erudit.org/fr/usagers/politique-dutilisation/ 


\title{
PRESIDENTIAL ADDRESS*
}

\author{
Hilda Neatby \\ University of Saskatchewan
}

It has often been said that Canadians are a conservative people. Presidents of the Canadian Historical Association are prone to introduce their annual addresses by reminding their hearers of what other presidents have done. I shall remind you of what one other President has said; in speaking of our neglect of other Canadians:

\footnotetext{
"There is a great need for biographical studies... And I should like once again to enter a plea in favour of the small-scale study - a 5000 word chronicle and character impression. ... One reason many people find Canadian history dull is that most of the characters that appear in it are mere shadows."
}

I could even quote myself on the same subject. I wrote a brief essay on Canadian historical studies some years ago and it seemed to me then that a notable weakness was the lack of sound readable biography. I could not say the same today. The last decade has given us some admirable interpretations of a number of great Canadians. One in particular fulfils another wish that I then expressed, that Frenchspeaking Canadians would work more on "English" aspects of our history and vice versa. Professor Eccles has given us his Frontenac in English. We need a French version of an English Frontenac - if we could find the English Frontenac. We need more studies which cross the boundaries of culture and language.

I am not going to attempt anything so pretentious to-night, but I am going to talk about a French-speaking Canadian - I might call him a "minor Canadian" - who yet played a significant part in the development of our country. I show some temerity in speaking of him at all, for les Canadiens are not in entire agreement in their estimate of him.

I am going to speak of him however because whether he was "right" or "wrong", "useful" or otherwise, I have learned, after some weeks of reading his letters, to respect and admire him, to pity and to laugh at him, to be moved by his mistakes and weaknesses and to be pleased by his successes, in short, to like him. Would I have liked him had I known him in the flesh? I don't know. But I like him in my historical recreation.

I am speaking of a man who lived and worked in the heart of this beautiful old city and who died here nearly two hundred years ago, a

* Jean-Olivier Briand: $A$ "Minor Canadien", read before the Canadian Historical Association, Laval University, Quebec, June 6, 1963. 
vicar-general of Quebec and later bishop of the diocese, Jean-Olivier Briand.

Briand illustrates the plight of so many of our national figures. Caught in difficult times, hurled into controversies which in our ardour we cannot let die, they are bottled and labelled according to their party, their "significance", their "contribution", and it is most difficult to get at the live person, to tear off his label, and to see him as a man. Briand has been all but canonized by the Abbé Gosselin, (bottled one night say in the sweetest and heaviest of syrup); he has been labelled with benign but passing approval by Professor Burt. He has been, more recently, somewhat severely treated by that meticulous scholar Professor Marcel Trudel who, I need not say, knows much more about Briand and his Church than I do.

I do not propose to attach any fresh label to Briand. I certainly do not propose to attempt any final evaluation of his contributions to church or state, to Canadian religion or culture. I want to-night only to offer a sketch of him as he appears in his correspondence with Canadians of every rank and occupation, an earnest, conscientious man loaded with responsibilities which, it seems clear, he had not sought and which he felt to be beyond his powers and yet which, stubborn, tough, persevering Breton peasant as he was, he would carry because he must.

Born in 1715, Briand was consecrated priest in 1739. He sailed for Canada only two years later in 1741. On the same ship was the then Bishop of Quebec, Mgr. Pontbriand. Pontbriand was much impressed by the young man and ultimately used him, apparently, as secretary and assistant for nearly twenty years. The death of Mgr. Pontbriand on May 8, 1760 left the see vacant at the very moment when the Capitulation of Montreal ceded the country to the English. Briand was not "capitulary vicar", but, as vicar-general at Quebec and apparently in some fashion designated by Mgr. Pontbriand for this role, he did assume some leadership in the crisis. As is well known, the Quebec Chapter, anxious to secure a bishop, "elected" Montgolfier, the able and distinguished head of the wealthy Seminary of Sulpicians at Montreal. The election was not approved at Rome; Montgolfier was not approved by the English authorities at Quebec. By subterranean and tortuous methods Briand, the choice of General Murray, passed from Quebec to London and from London to Paris (tactfully avoiding any obvious contact with Rome) and then, in 1766 back to Quebec, now officially recognized in London as "the Superintendent of the Romish Religion". So he remained until 1784, when his Britannic Majesty was graciously pleased to consent to his retirement, with a comment on his long and faithful services and his virtuous life. This was London. But he had been consecrated bishop in France on the authority 
of Rome, and before long in Quebec he was "the Bishop" to everyone from the English governor down.

$\mathrm{He}$ was not an ambitious man; he seems even to have been a really humble one. He protests to the late bishop's sisters: "What a horrible disaster. Here I am in London seeking the office of the late Mgr. Pontbriand. I resisted as much as possible."1 $\mathrm{He}$ goes on to say that he sees the late bishop from heaven imposing on him repugnant duties as he did in life, and all for his own good. This may seem overdone, and one does get rather tired of Briand's repeated wishes that he could be relieved of his office; but he apparently never did get illusions of his own grandeur.

At the same time he took the duties and authority of his office with immense seriousness. If his connections with Rome were devious they were none the less essential. The Canadian church in his view was a part of the only church recognized by the Almighty, and it had fallen to his lot to rule and organize, to nourish and sustain it, in very grievous times. M. Trudel has shown how the number of Canadian priests was falling below the needed strength even in the few years between the capitulation and the official inauguration of British rule in 1763. The appointment of a bishop made ordination of Canadians for the parishes possible, but the conquerors would permit no priests from France and (even before the dissolution of the Jesuits in 1773) it was a question whether the men's religious orders could recruit at all. How could the parishes be maintained, missionary work carried on, seminarians selected, educated, given theological training?

This was not the most immediately teasing question. The Church in Canada had hitherto been supported and sustained by the authority of government, the habits of society, and the simple fact that there was no other church. Priests and people could be subjected to a discipline which might generally be easy because it would always be firm. But now not only were Protestants pouring in, but the old single undivided allegiance to church and king together was torn apart. Men must obey (and the church must teach them to obey) an alien and heretic government. Some would resent this and revile the church that imposed on them such a rule. Others would appeal to their new governors against the authority of the church and so make a mockery of discipline and good order. An adequate, united and dedicated priesthood might hope to hold together the church. But the priesthood in Canada was not entirely united or completely dedicated. This was, after all, the eighteenth century, in England and France alike a strange combination of great piety and much ecclesiastical worldliness.

1 Montreal, Archives du College Ste-Marie. B.1.b.1000. Briand to sisters of Pontbriand. February 12, 1765. 
To these problems Briand addressed himself with energy, with courage, and with faith. His first, his most responsible and frustrating task was the management and encouragement of his little band of priests on whom so much depended. Throughout his career he exhorted ceaselessly to virtue, prudence, and obedience.

He exhorted to virtue. Some needed to be reminded so often and so forcibly that a reading of the letters can give a false impression. As M. Trudel has noted "le bien ne fait pas de bruit", and no doubt the great majority of the priests were, in intention at least, men of integrity, diligence, and devotion. But their task was hard, they were isolated, and no doubt often perplexed and tempted. There is no reason to suppose that Briand looked for trouble, but he remarked himself in the early days when he was still only vicar-general "there is hardly any priest that I have not been obliged to rebuke if you except eight or ten". 2

Of some he might remark mildly that they were good priests but a little wanting in self-denial: "Great men have these weaknesses". About others he was sharp and shrewd. A missionary to the Indians gives him anxiety: "For a long time I have known that he likes a horse better than the Bible, that he does not study at all, and that he is extremely ignorant."'3 Another he rebukes directly for yielding to the universal temptation: "You are always visiting among the people, and you are most assiduous in houses where there is brandy", adding that, if he could not be accused of being drunk in public, his manner too often was unsuitably gay. This man bore the rather genial name of Gaillard. ${ }^{4}$ One whose conduct was apparently generally displeasing was urged not to imitate the shepherds who drink the milk of the sheep and clothe themselves in their wool, and then cut their throats. ${ }^{5}$ And to one who was for some time a cause of considerable anxiety he offers a rebuke that seems to leave very little unsaid: "It is very difficult not to accuse you of malice, deceit, dishonesty, cheating, bad faith and greed". But having enlarged on these matters he closes the letter quaintly but quite characteristically "Do not give me any more anxiety in this matter in order that I may never lose the sentiments of esteem, affection and respect with which I always have been and am still, etc."6

There was much more than formal courtesy here. Briand, in modern terminology, used the positive approach. There are innumerable invita-

2 Quebec, Archives of Archbishopric. Copies des Lettres, v. 3, p. 141. Briand to perrault, [April?] 1762 .

3 Ibid. p. 289. Briand to St. Onge, September, 1766.

4 Ibid. p. 51. Briand to Gaillard, March 6, 1761.

5 Ibid. p. 285. Briand to Father Theodore of Beauce, September 16, 1766.

B Ibid. p. 41. Briand to Maisonbasse, (St. Thomas) February 21, 1761.

6aIbid. p. 99. Briand to Porlier, March 24, 1762. Ibid. p. 133. Briand to Porlier, 1762. Ibid. p. 55. Briand to Lagroix, November 13, 1761. 
tions to goodness from his pen; some are very lengthy and diffuse, but almost all are affectionate, showing a constant desire to believe the best, warring with a certain native shrewdness which tells him that the worst may be more probable. ${ }^{7}$ To all, and especially to those whom he has ordained, there is evidence of strong affection. To a young missionary in the Illinois country: "May our Lord be with you ... . May he preserve [through life] the missionary spirit and goodwill that you manifested to me when I ordained you. Pray for me as I do for you."

It was not only virtue but prudence that the priests needed, and Briand cultivated as he could the wisdom of the serpent. Priests must, of course, work hard at their business, not lose a moment that can be given to study, ${ }^{8}$ and they must be constantly aware of their difficult position in relation to the government, alien in religion, to which they owe allegiance. They must carefully observe the law for "c'est un grand nom chez les Anglais", 9 but they must avoid litigation. ${ }^{10}$ They must not carry their own suggestions or complaints to the governor, ${ }^{11}$ but they are to remember to pay courtesy calls when they are in Quebec as this is expected (at least by Murray). ${ }^{12}$ They are not to express views publicly on public affairs, and advice even in confession must be given with much caution. ${ }^{\mathbf{1 3}}$ This last exhortation was accompanied with the remark that in the particular instance under discussion the priest would have been reproved for such meddling even under the French régime.

Those in the up country posts, responsible to the local commandants, were in a particularly difficult position, especially when there were requests, backed by authority, for the immediate celebration of marriages for which a dispensation from the bishop was required. The whole question of marriages and of burials, especially before the passing of the Quebec Act, was extremely difficult. Marriages between Catholics and heretics, says Briand, are valid but not allowable. The priest may neither bless them nor be present at them. ${ }^{\mathbf{1 4}}$ When marriages require a dispensation, this dispensation may never be accepted from the commandant, the representative of the state. Better, in an extreme case, for the priest to issue the dispensation himself. ${ }^{15}$ As for burials, if Catholics are compelled to share burying places, with Protestants (in the Illinois country, for example) they must yield quietly. If the priest feels the place to have been polluted by the burial of a heretic he can bless afresh

7 Ibid. pp. 568-9. Briand to Gibault, April 26, 1769.

8 Ibid. p. 75. Briand to Brother Theodore, January 20, 1762. Ibid. pp. 567, 607. Briand to Gibault.

9 Ibid. v. 4, p. 77. Briand to Gatien, December 26, 1770.

10 Ibid. v. 3, p. 161 . Briand to Duchouquet, November 5, 1761.

11 Ibid. p. 591. Briand to Filion, June 26, 1769.

12 Ibid. p. 107. Briand to Dufrost, May 1762.

13 Ibid.

14 Ibid. v. 4, p. 95. Briand to Father Meurin, Illinois, March 22, 1770. 3,1768

15 Ibid. v. 3, p. 441 . Briand to Father Simple Bocquet, at Detroit, September 
every Catholic grave as it is made. ${ }^{16}$ And, as a general conclusion to the up country priest: "Try always to get along with the commandant and with all the English and even as far as the altar yield them nothing in politeness and affability." 17 And again to a missionary in the Illinois : "As to ecclesiastical laws, temporize. Consult us and act with moderation until you get our reply. If the commandants become angry or wish to trespass, it is better, when possible in conscience, to yield rather than to break with them."18

It was all very well to write and exhort. The peculiar difficulty of Briand's position lay in the fact that, accustomed to the order and discipline of the hierarchy supported by ecclesiastical monopoly and the countenance of the state, he now found himself at the head of a "voluntary" and yet a still rigidly authoritarian church, in the unhappy position of complete responsibility and no power. No power, that is, beyond his moral power to appeal to custom and tradition, to piety and to faith, and, incidentally, to the fear of hell, an appeal which he used with a certain freedom. Had Briand been a Protestant he would assuredly have been, as one would say, well to the left, perhaps an oldfashioned Methodist.

Briand grasped the implications of his position, took his stand early and held to it firmly. He would maintain discipline and authority within the Church at all costs. His letters not infrequently rebuke priests for replies which are insolent or "indécents" $;^{19}$ for being defiant, as when they remind him that even if deprived of their cures they have enough to live on, "cities of refuge and fortresses in which to defend themselves against discipline" is his wrathful comment) $;^{20}$ for making excuses when summoned to Quebec to explain themselves and possibly to be reprimanded. The depth of the snow, he remarks to a priest summoned in October and not yet arrived in January does not seem to have prevented him doing a lot of travelling to places other than Quebec. Was it the sick that he was visiting in l'Islet?21 If some priests did not want to travel other people did, and Briand seems to have been able to keep well-informed about what was going on by those who came to complain, or merely to gossip. ${ }^{22}$ At the same time Briand was very careful never to appear before outsiders to believe anything against his clergy. When he thought it necessary he proceeded from rebuke by letter to summons to Quebec, to transfer to another parish, to partial deprivation of powers. In extreme cases he seems generally to have

16 Ibid. v. 4, p. 95. Briand to Father Meurin, March 22, 1770.

17 Ibid. v. 3, p. 441. Briand to Father Simple Bocquet, September 3, 1768.

18 Ibid. p. 568. Briand to Gibault, April 26, 1769.

19 Ibid. p. 149. Briand to Trutaut of Kamouraska, February 2, 1763.

20 Ibid. v. 4, p. 71. Briand to Gatien, December 26, 1770.

21 Ibid. v. 3, p. 65. Briand to Brother Theodore at Beaumont, January 12, 1762.

22 Ibid. p. 95. Briand to Duchouquet of St. Pierre du Sud, March 24, 1762. Ibid. pp. 57, 59. Briand to Father Didace, St. Joseph de Beauce, October 1, November 11, 1761. Ibid. p. 79. Briand to Ménage of Deschambault, March 16, 1762 . 
sent the priest to live for a time with one of the more reliable clergy and to give such help as he could, Briand paying for his board. ${ }^{23}$

These extremities were reached only very gradually. For example to Dolbec, priest of l'Islet, he writes in 1762 (when he was still only vicar-general) how happy he is that Dolbec has defended himself on matters charged against him, but he would like to see him after Easter. He hopes an order won't be necessary: "A little cordial explanation between us two will do no harm." By October all is well: "I have no complaint about you for some time and I am delighted. I admit that it is hard for inferiors to be uncertain if their superior is satisfied with them. But isn't it also very hard on a superior to be uncertain if his inferior is doing his duty?"24 By the following April, Dolbec was in hot water again over an irregular marriage. Peace ensued (as far as the letters show) for a few years and then, in the autmun of 1767 , it appears that even after renewed exhortations Dolbec has forgotten his promises to return to God. The bishop is horrified at what he hears and must see Dolbec immediately in order to take measures "which I will still try to make as little disgraceful to you as possible". By January 1769 Dolbec gets a really fearful rebuke running into many hundreds of words. This time, it seems, he has gone the limit and appealed to the governor, and at that none too humbly, against the bishop. He is to be expelled from his parish and presbytery by two neighbouring priests, and we find him a few days later the guest of one of these who is charged to do all he can for him. ${ }^{25}$

And yet from kindness as well as from common sense and prudence Briand used his powers seldom. He was very willing to restore those who even seemed to be penitent. He expended himself in giving kindly and tactful advice on how to deal with difficult parishioners, (deal firmly with the men, don't refuse the women the sacrament unless they are "furieuses", avoid any discussion with children, but if unavoidable try to persuade them not to take sides). ${ }^{26}$ And he gave good counsel to the young missionary in the Illinois country, telling him to try not to assume too readily that his older colleague has reached his second childhood. Father Meurin's letters, says Briand, do not sound senile.

"Experience will teach you many things... Everyone newly entered into the ministry is naturally inclined to judge his elders rather too severely or with too much indulgence. I have gone through this stage; you get over it and you are obliged to admit that you have been mistaken." 27

23 Ibid. p. 87. Briand to Dufrost, St. Joseph de Levis, February 6, 1762. Ibid. p. 549. Briand to Duburon, January 20, 1769. Ibid. p. 416. Briand to Maisonbasse, March 13, 1769. are drafts.

24 This may be merely a note of a letter written. Most of these office copies

25 Ibid. v. 4, p. 187. See also Briand to Porlier, January 18, 1771.

26 Ibid. pp. 413, 416. Briand to Maisonbasse, priest of St. Thomas de Montmagny, February 27, 1768, March 13, 1769.

27 Ibid. p. 607 ; v. 4, p. 91. Briand to Gibault (Illinois), August 13, 1769, March 22, 1770 . 
But with a constant sense of the need to be tactful, a kindly instinct to soften his own severities (attached to the office copy of a letter ending with a really scorching rebuke is a note of the exceedingly mild and almost affectionate admonition which had been substituted ${ }^{28}$ Briand does not seem to have changed his early view expressed to Montgolfier at Montreal

“... I would rather see a good priest charged with two or three parishes than to use some who do not instruct the people but on the contrary scandalize them and lead them into sin by their example and leave them groping by the indulgence of the confessional and the casualness of their ministry."20

And he sent a typical note to a priest at Three Rivers whose conduct he disapproved.

"I don't ask for gratitude but I want obedience and do not think that I will demand it the less because we are under the English government. It is just and proper. Don't get a false notion of liberty; it doesn't justify insubordination." 30

One special problem that met Briand shortly after his return as Bishop was the dissolution of the Jesuit order by the Pope. Already Jesuits were forbidden to recruit by the English, but Briand needed the services of those who were left. His views, as it happened, were particularly furthered in this matter by Cramahé, who was most anxious at this critical time to do nothing to weaken ecclesiastical authority. Lieutenant-governor and Bishop worked out a modus vivendi. Briand did not publish the bull of dissolution, but he did convey it privately to the Jesuits, who submitted with much humility. Briand himself became the "superior" of a community which was no longer Jesuit, but the Fathers continued to wear their usual garb and to discharge their priestly functions. In fact Briand ordained two brothers to be priests. The Jesuits continued to manage their own property until the death of the last of their order in Canada who had retained complete control of the income from which he gave large sums in charity. No one beyond the Jesuits themselves, the bishop, the governor and his secretary, knew that as an order they had ceased to exist in Canada, a situation without parallel, I believe, except in Russia where Catherine refused publication of the bull. ${ }^{31}$ Catherine felt no particular responsibility to Rome, but Briand did, and, having read his rather complacent account of the good arrangements he had made, one wonders how he explained his disobedience to his ecclesiastical superiors.

He reported his doings in this matter or rather his lack of doings, in the course of one of his long routine letters to Cardinal Castelli at

28 Ibid. v. 4, p. 187. Source not identified. See also Briand to Porlier, January $18,1771$.

29 Ibid. v. 3, p. 125. Briand to Montgolfier, October 22, 1762.

30 Ibid. p. 395. Briand to Father Couturier, 1767.

31 Ibid. pp. 181, 377. "Memoir on the College of Quebec". Montreal, Archives du College Ste-Marie. B.I.b.1020. "Memoir on the diocese of Quebec in 1794". 
Rome. The cardinal answered the report, touching carefully on all paragraphs except those affecting the Jesuits. On these he said precisely nothing. ${ }^{32}$ And there the matter rested. Briand's arrangements were neither approved or rebuked. To the libertarian Protestant the workings of authoritarian Rome are a never failing source of wonder and surprise.

A most serious responsibility of Briand as vicar-general and as bishop was the well-being and good conduct of the various communities of nuns whose kindly and essential services in caring for the sick as well as in the education of young girls had been warmly praised by their good friend and protector, the fierce Protestant, Murray.

Murray's praises were warmly echoed by a later bishop (Hubert), but an examination of Briand's letters shows that the nuns like the priests occasionally caused anxiety, and even aroused his generally fleeting wrath. This was as I have said, the eighteenth century and there is evidence that the relaxed outlook of many communities in France might have had some influence even on the more puritanical colony of the St. Laurence. A long letter to the nuns at the General Hospital who wish to receive novices, relates the many faults, the excessive worldliness, the indiscipline which make them in the eyes of the Bishop very unfit to do so. ${ }^{33}$ And the Ursulines are gently admonished for using coloured curtains and counterpanes and, surprisingly, fashionable shoes! ${ }^{34}$ A more happy and most kindly communication goes to one who has just been chosen mother superior (when and of which house is not stated). She is urged to do, what indeed the bishop himself does, take a "positive" line in the exhortation of her nuns:

... Do not say to a proud and haughty girl "You are proud and haughty" but rather, "My daughter be more humble. There is some appearance of pride in what you have said or done". And to an angry girl "Be more gentle ... try to dominate anger".

Such rebukes, he argues, are the most efficacious in producing repentance. He adds, shrewdly as well as kindly, that thoughtful inquiries after those with poor health will enable them to make greater efforts than would otherwise be possible. ${ }^{35}$

But the vials of wrath were emptied on all concerned on the day when an Ursuline took, from the lay viewpoint, an apparently blameless "day on the town" slipping out of the convent at 4 a.m. when the supplies were brought in for the day and, by permission of the bishop, returning under the somewhat grim escort of the chaplain, the Jesuit

32 Ibid. Briand to Cardinal Castelli, November 6, 1774. Quebec, Archives of Archbishopric. Cartable, Evêques de Québec I, 173.162. Briand to Mesdames de Pontbriand, November 1794.

33 Ibid. v. 4, p. 43. Briand to the Nuns of the General Hospital, [176?].

34 Ibid. p. 343. Briand to the Ursulines of Quebec, April 3, $177 \dot{2}$.

35 Quebec, Archives of Archbishopric. Copies des Lettres v. 4, p. 37 . Briand to Rev. Mother Superior. [No name. No date]. 
Father Glapion, to be received at the entrance by the superior, the portress and the "zélatrice" and conducted to her cell, where it would appear she was to remain for some time, her conversation restricted to the superior and the nun who brought her meals, neither of whom it may be supposed would be chatty. ${ }^{36}$

There are no details on this curious incident beyond the meagre ones in Briand's letter to the superior. It seems quite clear that the errant sister did not seek the entertainment of the waterfront or the bishop would almost certainly have said so. Personally, I would like to think that she was young and homesick and had an uncontrollable desire to climb Cape Diamond on this lovely July morning and look wistfully up or down the noble river in the direction of the little village that had been home. But I am a post-Wordsworthian sentimentalist and this young woman, if she was young, could not have read Wordsworth and almost certainly had not read Rousseau. What seems most probable is that she had family or friends in Quebec and, perhaps lonely or discouraged or having somehow heard of a family gathering, slipped away for a visit, only to be quickly persuaded to repent and return.

A less scandalous but more prolonged congé was taken by two sisters of the Congregation in Montreal, who were not cloistered, but who caused some little difficulty. They finally got down to Quebec and had an audience with the bishop himself. His reception of them exhibited all the native shrewdness which underlay and generally controlled his verbosity and emotionalism. "Pour m'épargner une foule de niaiseries et de sotttises" he insisted that every word they said to him should be taken down in writing. ${ }^{37}$ One can only pity the poor ladies, burdened with the tale of their grievances and longing to pour it out in a flood, finding the very source of their eloquence dried up as they were compelled to wait on the remorseless scratching of the carefull quill pen. It even seems a little unfair on the part of Briand who, fond as he was of pouring out his views at length, might have been more sympathetic. No doubt he felt that a Bishop was one thing and these humble sisters quite another.

And yet it does seem that Briand was an unwilling bishop. Writing to Marchand a vicar-general in the district of Montreal and a close friend of many years standing, in July of 1765 , he explained that he could hardly bring himself to take the steps "that will secure for me a burden for which I have an extreme repugnance."38 After he became bishop his depression continued and he longed to turn over the work to a successor. Marchand endeavoured to encourage him: "Before be-

36 Ibid. v. 3, p. 331. Briand to Rev. Mother Superior of Ursulines of Quebec, July $18,1770$.

37 Montreal, Archives of Archbishopric. Briand to Marchand, October 6, 1766.

38 Quebec, Archives of Archbishopric. Copies des Lettres v. 3, p. 218. Briand to Marchand, July 16, 1765. 
coming bishop you could not preach, now you easily overcome that timidity that you could not conquer before; you speak to your people with grace and force, zeal and unction."'39 Briand's reply was emphatic and apparently sincere. "There is no need to tell me . . . that I have no more talent for governing than I have inclination". As for his preaching, he speaks of the cost to himself, his embarrassment even to blushing,

"... an address which has neither tail nor head. It is no cheap humility which makes me speak thus. It is the truth. I have not the ability to preach well, but I have too much not to realize that I do so pitifully."

And he seems again to refer to a determination to lay down the burden as soon as a successor can be secured. ${ }^{40}$

If Briand had a low opinion of himself there were some who unlike his friend Marchand had a low opinion of him. There was indeed a party in Quebec who apparently thought a bishop and the episcopal authority unnecessary and said so. Briand in some indignation sent off to Cardinal Castelli a list of epithits applied to him - "proud, distant, haughty, imperious, ambitious, choleric and passionate"; "hard and imperious". "Some of them have said that I was a protestant and that I was destroying religion. I have been told to my face that I was " $u n$ chien de Breton entêté". ${ }^{11}$ His own people, he says, show him less respect than the English Protestants do. ${ }^{42}$

Briand defended himself to the cardinal, referring to the diligence and simplicity of his life. "I cenfess that I am charged with sins before God, but not "with scandalous faults". ${ }^{43}$ What is credible in the rather repetitious list of adjectives quoted is that Briand might be both choleric and stubborn. His "pride" I think boils down to a determination to hold together the church of which he was the unwilling bishop, to continue worship without persecution and to maintain the link with Rome. If he had pride, it was a very purposeful professional pride and it is clearly exhibited in his official policy.

First, there was to be no compromise. As bishop he was the father and the ruler of his flock standing in the place of Christ. Discipline, he reminded his people, had always been most rigid during times of persecution in the church.

39 Quoted from Rapport de l'Archiviste de la Province de Québec, 1929-30, Quebec, 1930, p. 71. Marchand to Briand, October 4, 1767.

40 Quebec, Archives of Archbishopric. Copies des Lettres v. 3, p. 354. Briand to Marchand, October 28, 1767.

41 Quebec, Archives of Archbishopric. Copies des Lettres v. 4, p. 128 . Briand to Castelli, 1774.

42 Ibid. v. 3, p. 599. Briand to the Marguilliers of Three Rivers, August 11,

1769. Ibid. p. 406. Briand to Marchand, January 30, 1768.

43 Ibid. v. 4, Briand to Castelli, 1774.

43aIbid. p. 162. Briand to Habitants of Machiche, October 22, 1780. 
"It must be more so today than under the French government because that is the only way we have to hold the people. The wicked will leave; we need not regret their loss if they are causing the flock to suffer." 44

"If they will not give obedience they know what to do". "There is another religion, they are perfectly free. I want to enjoy the one our Lord has given me." 45

"I would rather they were damned in following a false religion than in professing the true one."

But it was not so simple as that. Briand's flock for the most part had no thought of damning itself in a false religion, but one could stray a long way in the true one without being damned beyond repair. "I thought I knew the Canadians," wrote the Bishop to the habitants of Repentigny. "I saw them as a people docile submissive easy to lead, religious, attached to the faith..." But since his return as Bishop he had found "indocility, obstinacy, rebellion, ill-will against everything connected with religion and worship." $46 \mathrm{He}$ also, as he states elsewhere, found them prone to prevarication, and his colleague at Montreal, the bland Montgolfier, was inclined to agree: "I did not more than half believe their story" is a recurring comment in Montgolfier's letters to Briand.

Briand was tireless and vigorous in exhortations practical and moral. The habitants must build churches and presbyteries, and he tells them just how and where; this occasionally leads to bitter strife with the parishes threatening the bishop with a law suit and the bishop the parishes with an interdict. They must (in one instance) clear, fence and drain a cemetery, build stable, barn and hen house, fence a garden and supply wood for three years, if they want one of his dwindling stock of priests. ${ }^{47}$ As for tithes, there was much correspondence. The habitant had convinced himself that he paid them only when he was in a constituted parish with a regular priest. This Briand would by no means allow. Tithes were an obligation from all. Woe to the church if they were not well used, but even avarice and luxury on the part of priests do not excuse the people from paying them. "How many habitants are lost for failing to give a handful of barley!"48

But Briand was not avaricious even for the church. There is not, in his letters one trace of the love of money, nor of bullying, nor of malice. He had the right to say that he respected others' rights and

44 Ibid. v. 3. Briand to Marchand, April 22, 1768. And see also v. 3, p. 299 [1765?] p. 381, [1767?] p. 435, (September 27, 1768 p. 515, [1768?] v. 4, p. 179, (January 14,1771 ).

45 Ibid. v. 3, p. 512. Briand to Curé of St. Peter and St. John, October, 26, 1768.

46 Ibid. p. 503. Briand to Habitants of Repentigny, December 9, 1769.

47 Ibid. v. 4, p. 102 . Briand to the Habitants of St. Cuthbert, September 10, 1770. See also v. 3, p. 169 (October 27, 1763), p. 189 (March 9, 1764) pp. 453-4 (April 4, 1774).

48 Ibid. v. 3, p. 365. Briand to Hingan of St. Ignace [1767?]. See also v. 4, p. 115 (April 18, 1770) p. 143 (August 16, 1770) p. 176 (July 22, 1784). 
had no natural wish to dominate ${ }^{49}$ and when he remarks of one who had strenuously and was still successfully opposing him: "He has not yet done enough to extinguish affection in a bishop who glories in never having hated anybody"50 one is forced to believe him.

For various offences Briand frequently threatened, but it seems very seldom imposed, the penalty of excommunication. His instructions for the ritual of excommunication or of the public penance which ended or forestalled it were, however, detailed and impressive. Such proceedings must have added a certain drama to the otherwise humdrum life in the parishes, and they were, no doubt, sincerely dreaded by most people. Even in extreme cases, however, it is sometimes possible to see the episcopal wrath cooling as the letter is being penned. A certain man, for example, is to confess his sin in public and stand at the church door holding a candle all through high mass - but by the end of the letter he need hold the candle only during his confession and the cure is expressly to forbid any reproaches from others; being penitent, the bishop explains, he may be more virtuous than they. ${ }^{\overline{1} 1}$ Briand in writing to his priests bemoaned the frequent need to threaten excommunication or interdict. Before the conquest, he remarks, some of the moral offences for which he imposes excommunication would have been punished by the galleys or worse; in spite of his usual reliance on gentle means he evidently sighs a little here for the secular arm. ${ }^{52}$

Although Briand would have agreed, and his letters show this, that his great task was to work within the church for order and discipline and zeal, he was always acutely conscious of the problem of relations with the secular power. If he welcomed the Quebec Act as an important victory, the attitude of many during the American invasion appeared to him a very dangerous reverse for his church. From the very beginning he had been quite clear on the duty of the habitant to the English government. He had taken the oath of allegiance; it must be kept. The English king was his ruler under God, and he must remember how fortunate he was to enjoy his religion under a government so strongly opposed to it. Those who supported the Americans disappointed and angered him. He was vigorous in urging his priests to recall the people to their duty, so much so that the habitants became a little bored with political sermons. In one of the parishes south of Quebec, as an obedient priest was expending himself in the good cause, some one at the back of the church shouted in tones of exasperation "C'est assez prêcher pour les anglais!"

49 Ibid. v. 3, p. 405 . Briand to Marchand, January 20, 1768.

50 Ibid. v. 4, p. 191. Briand, Memoir of Conversation with Deputés of Marguilliers [1768 or 9 ? ].

51 Ibid. v. 3, p. 421. Briand to Beriau [1768?].

52 Ibid. v. 4, p. 421. Briand to Gatien St. Croix, November 17, 1773. 
Briand on this occasion wasted no time on threats. He laid the offending parish under an interdict until the name of the culprit should be turned in. And, aware no doubt of the speed with which the story would travel, he imposed the same penalty (with the same condition) on several neighbouring parishes. ${ }^{53}$

One may sympathize with the disgruntled sermon-taster and hope that, after all, he didn't get caught. One must also sympathize with the harassed and angry Bishop. He was a Frenchman, not a Canadian by birth or upbringing. He could have returned to France; he stayed in Canada to save the church. A necessary condition of that, in his view, was the loyal acceptance of British rule, even though when he spoke in private letters to friends of "the king" and "the queen" he certainly did not mean George and Charlotte. He may have been ignorant of the lot of Huguenots in France; he must have known something of the conditions of Roman Catholics in Ireland. He certainly knew the situation of Huguenots in New France.

A general duplication of this European discrimination and persecution in the parishes along the St. Lawrence, however impossible it may seem from the viewpoint of the twentieth century, was not a risk that could be entirely ignored even in the eighteenth, as the writings of the Huguenot lawyer, Maseres, plainly show. Moreover, Briand had to secure something beyond mere tolerance and independence for the church. In England as in France, church and state were linked together; they were two aspects of one society. On the one hand the Canadian church needed official recognition and countenance; by its very nature it demanded something beyond the bare toleration accorded to English Non-Conformists. It needed, for example, government countenance for public processions, for marriage usages, for all kinds of claims connected with property and civil rights. ${ }^{54}$ On the other hand, the British government needed an official church. In the absence of any system of public education or information the clergy were an essential element in maintaining among the people that unquestioning cooperation, docility and loyalty to established power which, however odious it may be to the modern mind, is still a humane and moral substitute for military terrorism and a secret police. It would be absurd to suggest that the vicar-general at Quebec saw all this clearly in 1763. But there seems to be no doubt that, astutely feeling his way, claiming where he could, yielding where he must anything permitted by conscience, he did in fact in twenty years establish his church effectively as the equivalent of the state church. If London knew him only as "the Superintendent of the Romish Religion", in Quebec, as I have said, he

53 Ibid. p. 585. Briand to Lacroix, October 1, 1775.

54 For example, Ibid. v. 3, p. 409, (January 28, 1768), p. 525, (December 1768), p. 571, (May 1769). Here the courts decided the issue but the Bishop prevented what might have been an awkward clash between church and state. 
was the bishop to everyone from the governor down. When the first Anglican bishop arrived he found himself almost automatically with a denominational label, to him a position as odious as it was novel.

The victory, for it was a signal victory, was not achieved without difficulty. Murray, kind and generous to the nuns whom he liked and whose services he valued, undoubtedly took an Erastian or, perhaps one should say, an extremely Gallican view of the church. Briand learned not to announce the appointment of a priest, but to ask permission to appoint him ; and to accept nominations of Murray which he disapproved, and with good reason $;^{55}$ and even to give courteous explanations when Murray inquired into cases of ecclesiastical penalties such as refusal of the sacraments. ${ }^{56}$ But all this seems to have been not so much weakness as a careful calculation of what might and therefore must be yielded. On one occasion, even as he yielded, he administered to Murray what, properly understood, could only have been taken as a rebuke. Murray had apparently requested temporary admission into a cloistered area for a Mlle. Desgoutins, and offered to pay for the privilege. Briand stated with great explicitness that such entry was forbidden by the rules and that to relax them for money would be a crime. "The wish of His Excellency is a more noble motive and more than sufficient and I make it my duty and honour to accord it." "ar

In the matter of prayers in church for a heretic king, Briand had much searching of heart, and he yielded more than his colleagues at Montreal and Three Rivers and more than some in Quebec would have wished. He seems to have acted on principle and not from timidity. $\mathrm{He}$ could not find that the rules forbade public prayers for any not specifically excommunicated; it was proper to pray for the King; and the arguments pressed on him that it was hard to pray for one's enemies he decided, reasonably, were unacceptable. However, in requiring jrayers for the monarch, he was careful to add no personal eulogy, and certainly no suggestion that his religious example was one to be followed..$^{58}$

But with all this apparent yielding no governor really got much beyond the church door. In the matter of refusal of sacraments: "I have had the honour to tell him [Murray] that neither I nor the Pope himself could do anything about refusal, delay or concession of absolution, because penitence was a secret and private tribunal whose judge would account only to God." 59 His own power as bishop came to him not from the King but from the church. "What I have from

55 Ibid. pp. 123-6. Briand to Montgolfier, October 22, 1762.

56 Ibid. Briand to Murray, April 7, 1763.

$57 \mathrm{Ibid}$. Briand to Murray, December 16, 1762.

58 Ibid. pp. 93-4. Briand to Montgolfier, [February 22?] 1762. Ibid. p. 67. Briand to Perrault, February 22, 1762.

59 Ibid. p. 173. Briand to Blondeau, November 19, 1763. 
the king is liberty and permission to exercise my ministry and use my powers." 60

Briand's reward for conciliation was the bishopric which he did not want. Much more, it was the appointment of a coadjutor to ensure the succession, a step authorized by Rome in 1766 but postponed for four long years in Quebec even by the obliging Governor Carleton. And it seems clear that here again Briand had to conciliate in practice in order to win in principle. A discreet attempt to find out who would be acceptable to the clergy in the district of Montreal offended he governor, ${ }^{61}$ and the man ultimately approved, or perhaps chosen, by Carleton was not the one Briand would have chosen. "Le gouvernement a consenti à un coadjuteur et a paru désirer $M$. Desglis; je n'ai pas cru devoir m'y opposer ; c'est un bon prêtre". ${ }^{62}$ Even the favoured M. Desglis was consecrated only after a "little storm" in which Catholics joined with Governor Carleton in urging that there was no need to wait for the papal bulls. This time however Briand did not yield. ${ }^{63}$

If the securing of a coadjutor was a triumph, much more was the practical guarantee offered by the Quebec Act, with the official oath so drafted by Briand as to be wholly inoffensive to Catholics. Briand, however, was laughed at and reassured by Carleton because he was still alarmed by what seemed to him the ominous reference to the Royal Supremacy in the Act itself. And yet even before the passing of the Act he had stated that he thought the episcopal powers of discipline and administration were greater than they had been during the French regime. ${ }^{64} \mathrm{He}$ meant by this, no doubt, that there was less direct interference from the governor, or, possibly, from authorities in France.

On the whole Briand was more than satisfied with his official connections. Chosen as bishop by Murray, the close friend of Carleton, liked even by Haldimand, (about whom, however, he wrote to Carleton with unwonted resentment) he spoke of these connections repeatedly with satisfaction, even with complacency. It was certainly a success story, and accusations of snob, sycophant, tool of the English can easily be made. I think that they are unjust. Did he yield unnaturally to the conquerors, compromising the dignity and independence of the Canadian church? I think there is evidence that he yielded no more than he had to, and no more than his conscience (and Rome) permitted. It was not for him a question of maintaining the dignity of the Canadian church against a foreign and heretic conqueror, but rather of surviving, and of contriving from day to day an uneasy balance between the claims of

60 Ibid. p. 333. Briand to Father Simple Bocquet, Detroit, [in 1766 or later].

(61 Ibid. p. 251. Briand to Marchand, April 25, 1767.

62 Briand to Marchand, January 22, 1770.

6.3 Ibid. v. 4, p. 153. Briand to M. de la Corne, July 27, 1770.

64 Ibid. v. 3, p. 145 . Briand to Montgolfier, January 1763. 
Caesar and of God. It is interesting that Canada anticipated the nineteenth century cleavage between church and state which, added to the growth of nationalism, was the occasion of such turmoil in Europe. In Canada the religious issue was settled, and peaceably, before the national one became acute. Religion undoubtedly has accentuated our racial-cultural divisions but it has never been, of itself, an issue. There has been religious prejudice in plenty, but no religious hatred. Was Briand who reported happily that "the English like our ceremonies" and that concession and courtesy to the civil power (even heretic) must be yielded "as far as the altar" responsible for this? I think he was, in part at least. If he seems sometimes a timid compromiser it is largely because in the eighteenth century neither national sentiment nor ultramontane sensitivity were as great as they later became.

But if not a nationalist nor an uitramontane, neither was he what today would be called an oecumenical. In order to keep alive in Canada what was for him the only true church he had to enlist by all honourable means the aid of the Protestant state. For this purpose his guileless friendliness and his shrewd simplicity were probably better adapted than Montgolfier's more sophisticated and detached intellectualism. One may suspect that when Murray rejected Montgolfier as bishop he served the church far better than he knew.

But problems of church and state and ecclesiastical politics offer an endless field for disagreement. My purpose has been less to clarify these problems than to suggest how Briand's letters may serve to reveal his own character and personality.

He was no stylist and, almost certainly, no scholar. His letters contrast sharply with those of his secretary (who became one of his successors), Hubert. Hubert is clear, firm, businesslike, neither friendly nor severe, but kindly and impersonal. Briand is never impersonal. It is not in his nature. He is emotional and verbose. His letters frequently reveal either anger or affection, and very often both. He can preach through page after page until the reader wonders whether he will ever finish the sermon and get to the point. He can, in a letter, offer up a long prayer in which (rather irritatingly) he lets the Almighty know just what he thinks of the disobedient children to whom the letter is addressed. ${ }^{64 a}$ And yet through all the religious verbiage which, the reader says to himself, almost must be mere cant, there comes the unmistakable impression of strength and sincerity. Perhaps some one has said the same things before but Briand if he knew, would not care. $\mathrm{He}$ is saying what he feels and knows. He even interjects an ardent exhortation on the character and calling of a priest in a letter to his colleague Montgolfier, vicar-general of Montreal and "évêque man-

64a Ibid. pp. $369-76$. 
$q u e ́$ "', not because Montgolfier needs it but because (as he is happening to speak of an erring priest) it comes into his head and he must say it. ${ }^{65}$

And always, with all the episcopal prayers, preachings and exhortations, there is just below the surface the shrewd sensible kindly and knowledgeable man of affairs, the deceptively simple man who knows and likes his neighbours but is not fooled by them, and is ready, if necessary, to let them know it; and most of all, the warmly affectionate man who, with all his thunderings truly loves people and wants to be loved by them. Reading these letters, preserved by the pious and practical care of the church, one can only regret more than ever the careless neglect or carefree vandalism which has deprived us forever of any real personal knowledge of so many other "minor Canadians". 